\title{
De Belgische evenwichtsoefening inzake de verplichte $A D R$-poging in het raam van een gerechtelijke procedure
}

\author{
Eric Lancksweerdt
}

\section{Inleiding}

1. Op 2 juli 2018 verscheen in het Belgisch Staatsblad de wet van 18 juni 2018 houdende diverse bepalingen inzake burgerlijk recht en bepalingen met het oog op de bevordering van alternatieve vormen van geschillenoplossing (hierna: 'wet bevordering ADR'). Door deze wet beschikken Belgische rechters voortaan over meer mogelijkheden om de partijen aan te zetten tot een minnelijke oplossing van geschillen. De Belgische regering had ambitieuze plannen wat betreft het bevorderen van alternatieve geschillenoplossing (hierna: ADR). Zo wilde zij onder meer dat rechters de mogelijkheid zouden krijgen om bepaalde vormen van ADR, zoals bemiddeling en collaboratieve onderhandelingen, ambtshalve te bevelen, ook zonder instemming van de partijen. Dat oorspronkelijke plan heeft de Belgische regering moeten bijstellen. Tijdens de behandeling van het wetsontwerp bleek al gauw dat er van verschillende zijden een sterke tegenkanting bestond tegen het verplicht opleggen van een ADR-poging. Zowel de Raad van State, de Hoge Raad voor justitie, parlementairen van meerderheid en oppositie en vertegenwoordigers van de magistratuur, de advocatuur en bemiddelaars bleken hiervoor allerminst gewonnen. Uiteindelijk werd een afgezwakte regeling goedgekeurd die op voldoende politiek en maatschappelijk draagvlak kon rekenen. In deze bijdrage worden de inhoud en de wijze van totstandkoming van de nieuwe regeling besproken. De zienswijze van de afdeling wetgeving van de Belgische Raad van State en die van de Belgische Hoge Raad voor Justitie krijgen daarbij speciale aandacht.

2. Deze bijdrage behandelt achtereenvolgens de volgende onderwerpen:

- de context van de nieuwe regeling, zowel op Belgisch als Europees vlak;

- het verloop van de wetgevingsprocedure;

- het ambitieuze voorontwerp van wet;

- de weerstand tegen verplichte ADR;

- bijgestelde ambities;

- enkele conclusies. 


\section{De context}

3. In België wordt relatief weinig gebruikgemaakt van ADR. Officiële statistieken ontbreken, maar er zijn sterke aanwijzingen dat ADR onderbenut blijft. In een Europese studie van 2014, gebaseerd op de inzichten van experts in bemiddeling in diverse Europese landen, werd het totaal aantal bemiddelingen in burgerlijke en handelszaken (dus niet alleen de bemiddelingen als al een gerechtelijke procedure is opgestart) in België op 2000 à 5000 geschat. ${ }^{1}$ In een 'bemiddelingsbarometer' die in 2016 werd gepubliceerd en die betrekking had op het jaar 2015, is sprake van in totaal 5.037 bemiddelingen, waarvan 3.210 in familiale zaken. ${ }^{2}$ Van collaborative law (collaboratieve onderhandelingen) wordt in België - en zeker in Vlaanderen - nog relatief weinig gebruikgemaakt, hoewel er bij de Frans- en Duitstalige balie een toenemende belangstelling voor bestaat. Deze balie heeft op haar website een informatiebrochure over collaborative law en een lijst van advocaten die willen werken volgens deze methode. ${ }^{3}$ Verzoeningspogingen door de rechter vinden vooral plaats bij de vredegerechten, veel minder bij andere rechtbanken. ${ }^{4}$ Een belangrijke nuance geldt voor familiezaken: sedert de inwerkingtreding van de Wet op de familierechtbanken in september 2014 heeft de rechterlijke verzoening in familiezaken aan belang gewonnen, en kunnen partijen door de familierechter zelfs verplicht worden doorverwezen naar de zogenoemde kamers voor minnelijke schikking bij de familierechtbanken en de hoven van beroep. ${ }^{5}$ Hoewel ADR zeer geleidelijk aan meer ingang vindt, blijft het voor veel partijen en hun juridische ondersteuners (zoals advocaten) moeilijk om de stap daadwerkelijk te zetten. Dit staat in schril contrast met de honderdduizenden civiele rechtszaken die ieder jaar in België worden afgedaan. ${ }^{6}$ De Belgische regering maakte sinds haar aantreden duidelijk dat zij iets wilde doen aan deze scheefgetrokken verhouding. Zowel in de regeringsverklaring ${ }^{7}$ als in de beleidsverkla-

1 G. De Palo, L. D’Urso, M. Trevor, B. Branon, R. Canessa, B. Cawyer \& L.R. Florence, Rebooting the mediation directive: assessing the limited impact of its implementation and proposing measures to increase the number of mediations in the EU, Brussel, Europese Unie, Directorate-general for internal policies - Policy department C., 2014, www.europarl.europa.eu/RegData/etudes/ etudes/join/2014/493042/IPOL-JURI_ET(2014)493042_EN.pdf, p. 120.

2 bMediation, Bemiddelingsbarometer 2016, www.bmediation.eu/images/stories/publications/ bemiddelingsbarometer\%202016\%20nl\%20final.pdf p. 6.

3 https://avocats.be/fr/le-droit-collaboratif.

4 M.J. ter Voert, Civielrechtelijke voorprocedures in België, Noorwegen en Duitsland. WODC Cahier 2013/1, Den Haag: WODC 3013, p. 15.

5 Wet van 30 juli 2013 betreffende de invoering van een familie- en jeugdrechtbank. Over de kamers voor minnelijke schikking, zie S. De Bauw \& G. Verschelden, 'De kamer voor minnelijke schikking en de bevordering van een minnelijke oplossing van familiale geschillen', in P. Senaeve (red.), Handboek familieprocesrecht, Mechelen: Kluwer 2017, p. 139-223.

6 Blijkens het justitieplan werden er in België 1.127.169 vonnissen en arresten uitgesproken in het jaar 2013. Daarin zaten echter ook strafzaken. Wanneer men de gerechtelijke uitspraken in civiele zaken (in de brede zin van het woord) neemt die werden gedaan door hoven en rechtbanken, dan komt men op ruim 300.000 uit. Daar komen dan nog eens ruim 450.000 uitspraken van vrederechters bij (K. Geens, Het justitieplan. Een efficiëntere justitie voor meer rechtvaardigheid, Brussel: FOD justitie, p. 13-15)

7 Regeerakkoord 10 oktober 2014, Parl. St. Kamer, 2014-15, nr. 54K0020/001, p. 123 en 127-128. 
ring van de minister van justitie ${ }^{8}$ leest men dat maximaal zal worden ingezet op de bevordering van alternatieve wijzen van geschillenbeslechting, zoals de bemiddeling, om de rechtbanken te ontlasten. Deze beleidsintentie werd herhaald in het justitieplan. ${ }^{9}$ De Belgische regering voegde de daad bij het woord en werkte een voorontwerp van wet uit dat ADR moet bevorderen. Dit voorontwerp leidde uiteindelijk tot de wet bevordering ADR.

4. Op het ogenblik dat de Belgische regering haar goedkeuring hechtte aan het voorontwerp van wet kon ADR slechts in zeer beperkte mate worden opgelegd door de rechter:

- bemiddeling was vrijwillig; ${ }^{10}$

- de collaboratieve onderhandelingen waren in het geheel niet geregeld en konden dan ook niet opgelegd worden;

- een poging tot minnelijke schikking bij de rechter was in principe niet verplicht, tenzij in de uitdrukkelijk bij de wet bepaalde gevallen. ${ }^{11}$ Zoals reeds aangegeven kon in familiezaken wel een doorverwijzing naar de kamers voor minnelijke schikking worden bevolen;

- andere vormen van ADR, behalve arbitrage, waren in het Gerechtelijk Wetboek niet geregeld.

\section{De wetgevingsprocedure}

5. Voor de lezer die niet vertrouwd is met de Belgische wetgevingsprocedure wordt hieronder kort toegelicht welke stappen werden gezet om tot de wet bevordering ADR te komen.

- Op 20 juli 2017 keurde de Belgische ministerraad op voorstel van minister van Justitie Koen Geens een voorontwerp van wet goed 'houdende diverse bepalingen inzake burgerlijk recht'. ${ }^{12}$ In tegenstelling tot wat het opschrift liet vermoeden bevatte het voorontwerp ook een hele reeks bepalingen tot wijziging van het Belgisch Gerechtelijk Wetboek. Zij waren erop gericht ADR te bevorderen.

- Het voorontwerp werd voor advies voorgelegd aan de afdeling wetgeving van de Belgische Raad van State. Zulk een advies moet verplicht worden ingewon-

8 Parl. St. Kamer, 2014-15, nr. 54K0020/18, p. 6 en 10-11.

9 K. Geens, Het justitieplan. Een efficiëntere justitie voor meer rechtvaardigheid, Brussel: FOD justitie, p. 25, 26 en 34.

10 Art. 1730 e.v. Gerechtelijk Wetboek hadden betrekking op de 'vrijwillige' bemiddeling en daaruit bleek dat bemiddeling inderdaad een vrije keuze van de partijen was. Art. 1734 Gerechtelijk Wetboek bepaalde dat een rechter een bemiddeling kan bevelen, maar enkel met instemming van de partijen. Art. 1731 Gerechtelijk Wetboek bepaalde dat het bemiddelingsprotocol dat aan het begin van de bemiddeling moet worden gesloten een herinnering bevat aan het principe dat de bemiddeling op vrijwillige basis geschiedt. Volgens art. 15 van de deontologische code moet de bemiddelaar toetsen of zijn aanstelling geschiedt op basis van de vrije keuze van de partijen (Beslissing van 18 oktober 2007 betreffende de gedragscode van de erkende bemiddelaar, goedgekeurd door de Federale Bemiddelingscommissie).

11 Art. 731 Gerechtelijk Wetboek.

12 www.presscenter.org/nl/pressrelease/20170720/diverse-bepalingen-inzake-burgerlijk-recht. 
nen bij elk voorontwerp van wet dat van de regering uitgaat. Het advies heeft vooral betrekking op de juridische, niet zozeer op de beleidsmatige aspecten van de voorgelegde tekst. De afdeling wetgeving bracht op 4 oktober 2017 een advies uit. Het was erg kritisch ten aanzien van een hele reeks bepalingen die betrekking hadden op het bevorderen van ADR. Adviezen van de afdeling wetgeving zijn niet bindend, maar kunnen bogen op een groot gezag. Afwijkingen ervan worden in principe goed gemotiveerd.

- De regering werkte het voorontwerp van wet bij tot een ontwerp. Zij kwam tot op zekere hoogte tegemoet aan de opmerkingen van de afdeling wetgeving. Waar dat niet het geval was, werd in de memorie van toelichting bij het ontwerp uitgelegd waarom. Uiteindelijk keurde de regering op 22 december 2017 het ontwerp goed. ${ }^{13}$

- Het ontwerp werd op 5 februari 2018 ingediend bij de Kamer van Volksvertegenwoordigers. De bevoegde commissie wijdde er verschillende vergaderingen aan. Diverse amendementen werden ingediend. De commissie organiseerde hoorzittingen en won schriftelijke adviezen in. Zo bracht de Hoge Raad voor Justitie een advies uit. De commissie keurde op 9 mei 2018 het geamendeerde ontwerp goed in een eerste lezing. ${ }^{14}$

- Er werd over het ontwerp een 'tweede lezing' georganiseerd in de bevoegde commissie. Deze had vooral betrekking op een reeks technische wijzigingen. Op 31 mei 2018 werd het ontwerp door de bevoegde commissie in tweede lezing goedgekeurd. ${ }^{15}$

- De plenaire vergadering van de Kamer van Volksvertegenwoordigers keurde op 7 juni 2018 het ontwerp definitief goed.

- De Koning ging op 18 juni 2018 over tot de bekrachtiging van het ontwerp.

- De wet verscheen in het Belgisch Staatsblad van 2 juli 2018.

\section{Een ambitieus voorontwerp van wet}

6 . Het voorontwerp van wet getuigde van veel ambitie op het vlak van het bevorderen van ADR door de rechter. ${ }^{16}$ Onder meer het volgende werd voorgesteld:

- De rechter bevordert in elke stand van het geding een minnelijke oplossing van de geschillen. Hij kan de partijen bevragen over de wijze waarop zij voorafgaand aan het geding gepoogd hebben het geschil minnelijk op te lossen en hen inlichten over de mogelijkheden om daar alsnog toe over te gaan. Daartoe kan de rechter de persoonlijke verschijning van de partijen bevelen. Hij mag uit de niet-naleving van deze beslissing elk passend gevolg afleiden. ${ }^{17}$

www.presscenter.org/nl/pressrelease/20171222/diverse-bepalingen-inzake-burgerlijk-rechttweede-lezing.

14 Parl. St. Kamer 2017-18, nr. 54K2919/007.

15 Parl. St. Kamer 2017-18, nr. 54K2919/010.

16 Dit voorontwerp van wet kan worden teruggevonden op p. 372-389 van het wetsontwerp houdende diverse bepalingen inzake burgerlijk recht en houdende wijziging van het Gerechtelijk Wetboek met het oog op de bevordering van alternatieve vormen van geschillenoplossing, Parl. St. Kamer 2017-18, nr. 54K2919/001 (hierna geciteerd als wetsontwerp ADR). 
- Op verzoek van een van de partijen of indien de rechter dit nuttig acht, kan hij de schorsing van de procedure bevelen of de zaak verdagen naar een vaste datum die een termijn van zes maanden niet mag overschrijden teneinde de partijen de mogelijkheid te bieden na te gaan of hun geschil geheel of gedeeltelijk op minnelijke wijze kan worden opgelost en daar alle nuttige inlichtingen over in te winnen. ${ }^{18}$

- De rechter kan ambtshalve of op verzoek van de partijen of een partij zolang de zaak niet in beraad is genomen bevelen dat zij hun geschil trachten op te lossen door een bemiddeling. ${ }^{19}$ Tegen een dergelijk bevel staat geen rechtsmiddel (bijv. hoger beroep) open. ${ }^{20}$

- De rechter kan ambtshalve of op verzoek van de partijen of een partij zolang de zaak niet in beraad is genomen een informatiesessie over bemiddeling opleggen. In dat geval beveelt hij tegelijk de persoonlijke verschijning van de partijen op die sessie. ${ }^{21}$ Tegen dergelijke bevelen staat geen enkel rechtsmiddel (bijv. hoger beroep) open. ${ }^{22}$

- De rechter kan ambtshalve, of op verzoek van de partijen of een partij, en na hen gehoord te hebben over de beoogde maatregel, zolang de zaak niet in beraad is genomen bevelen hun geschil door een collaboratieve onderhandeling trachten op te lossen. ${ }^{23}$

7. Ter verdere duiding van het ambitieus karakter van het voorontwerp van wet kan nog worden aangestipt dat ook advocaten in de mate van het mogelijke minnelijke oplossingen van geschillen dienen na te streven. Zij dienen de rechtzoekende te wijzen op de mogelijkheid tot bemiddeling, verzoening en elke andere vorm van minnelijke oplossing van geschillen. ${ }^{24}$ Een gelijkaardige verplichting geldt voor de gerechtsdeurwaarders. ${ }^{25}$ Verder kan nog worden vermeld dat bemiddeling in civiele zaken voortaan ook mogelijk moet worden voor publiekrechtelijke rechtspersonen. ${ }^{26}$

8. Uit het bovenstaande blijkt dat rechters, zelfs wanneer al een gerechtelijke procedure is opgestart, heel wat armslag zouden krijgen om de partijen in de richting van ADR te dwingen of te dringen. En, zoals hierna zal worden uiteengezet, kon dat helemaal niet op een brede instemming rekenen. 


\section{De kritiek op de verplichting tot ADR}

\section{Opmerkingen van de Raad van State}

9. Zoals aangegeven werd het voorontwerp van wet ter advies voorgelegd aan de afdeling wetgeving van de Raad van State. ${ }^{27}$ Deze betoonde zich uitgesproken kritisch. De afdeling wetgeving stelde vragen bij het feit dat het voorontwerp van wet, blijkens de memorie van toelichting erbij, niet zozeer tot doel had ADR te bevorderen, maar wel om ADR 'te bevoorrechten'. Daardoor wordt volgens de afdeling een logica gevolgd die ertoe leidt dat van een beroep op de rechtscolleges eigenlijk een alternatieve wijze van geschillenbeslechting gemaakt wordt die alleen kan worden aangewend voor conflicten die men niet heeft kunnen regelen via ADR. Dat die logica achter het voorontwerp zat, werd volgens de afdeling verder nog geillustreerd door het feit dat in de memorie van toelichting te lezen stond dat de beslechting via een rechtscollege als vangnet moet dienen wanneer alle andere minnelijke oplossingstrajecten niet mogelijk zijn, dat de beslechting van een geschil door een rechtscollege de laatste optie moet zijn, en dat in iedere stand van het geding voorrang moet worden gegeven aan bemiddeling of andere methodes om een geschil minnelijk op te lossen. Uit de ontworpen regeling bleek volgens de afdeling dat de rechter op verschillende manieren voor alle rechtsplegingen en in elke fase van de rechtspleging de minnelijke oplossing van een geschil dient te bevorderen en zelfs te bevoorrechten ten opzichte van rechterlijke uitspraken. Dit alles doet volgens de afdeling wetgeving een dubbel probleem rijzen. Ten eerste houdt de tekst een inperking in van het recht om zich tot een onafhankelijke en onpartijdige rechter te wenden om uitspraak te doen over burgerlijke rechten en verplichtingen, een recht dat is gewaarborgd door artikel 6 van het EVRM. Dat recht omvat ook het recht op een uitspraak binnen een redelijke termijn. Doordat het voorontwerp het mogelijk maakte een gerechtelijke procedure meermaals te schorsen - en zelfs tot op het einde van de procedure - teneinde de partijen toe te laten een ADR-poging te ondernemen en door de mogelijkheid van de rechter om ambtshalve te bevelen een bemiddeling te proberen of deel te nemen aan een informatiesessie, komt dat recht in het gedrang, vermits de duur die nodig is om ADR te proberen bovenop de termijnen voor de gerechtelijke behandeling van de zaak komt. Dit kan zelfs leiden tot een echte rechtsweigering. Het tweede bezwaar van de afdeling wetgeving was van principiële aard. Het ambtshalve bevelen van een bemiddeling, zelfs tegen de wil van de partijen, werd onverenigbaar geacht met het wezenlijk beginsel dat vrijwilligheid voorop dient te staan. Bemiddeling moet aanvaard worden door de partijen. De regeling hield volgens de afdeling een aantasting in van de hele filosofie die ten grondslag ligt aan de legitimiteit en efficiëntie van de aanwending van bemiddeling. De afdeling wetgeving was helemaal niet overtuigd door de uitleg van de regering dat de rechter de partijen niet tot een bemiddelingsakkoord dwingt. Op geen enkel ogenblik is door de rechtsleer of door voorstanders van de bemiddeling gesteld dat de vrijwilligheid van de bemiddeling enkel tot gevolg zou hebben dat de rech- 
ter de partijen niet tot een bemiddelingsakkoord kan dwingen. De afdeling wetgeving zag overigens niet in hoe de rechter aan de partijen een akkoord zou kunnen opleggen. Hoewel de partijen afstand kunnen doen van de rechten die hun zijn toegekend door artikel 6 lid 1 EVRM, dient dit steeds een weloverwogen en bewuste keuze te zijn. Daar komt bij dat een bemiddeling bijkomende kosten meebrengt, bovenop de kosten die al zijn gemaakt voor de gerechtelijke procedure, en dat zij niet noodzakelijk tot een resultaat leidt, waarbij het gevaar bestaat dat dit vaak het geval zal zijn als een bemiddeling aan de partijen of aan een van hen opgedrongen wordt. De afdeling wetgeving was verder nog van oordeel dat de rechter de partijen evenmin kan verplichten (collaboratief) te onderhandelen. Ten slotte was de afdeling van mening dat de mogelijkheid voor de rechter om de partijen te ondervragen over de wijze waarop zij voorafgaand aan het geding gepoogd hebben hun geschil minnelijk op te lossen, een fundamenteel probleem deed rijzen op het vlak van de vertrouwelijkheid van de onderhandelingen tussen de partijen.

10. Het advies van de Raad van State kon de regering er niet toe brengen om af te zien van de principiële mogelijkheid voor de rechter om de partijen tot een bemiddeling te verplichten. In de memorie van toelichting bij het ingediende ontwerp leest men dat deze mogelijkheid voor de rechter gehandhaafd blijft 'aangezien deze maatregel niet ingaat tegen de aard zelf van de bemiddeling, die vrijwillig is en blijft'. ${ }^{28}$ De rechter dwingt de partijen immers niet om tot een bemiddelingsakkoord te komen. De vrijheid om in te stemmen met de oplossing van het geschil door bemiddeling blijft behouden. De mogelijkheid wordt geboden om kennis te maken met bemiddeling door druk uit te oefenen op de weerstand ertegen. De bemiddeling wordt op geen enkele wijze opgelegd voor een zaak aanhangig wordt gemaakt bij de rechter. De rechter blijft over een beoordelingsmarge beschikken: hij kan een bemiddeling opleggen, maar is daartoe niet verplicht. De partijen blijven de waarborgen behouden die artikel 6 lid 1 van het EVRM hun biedt, aangezien zij vrij zijn om het bemiddelingsproces stop te zetten. ${ }^{29}$ In de memorie van toelichting wordt verder nog gepreciseerd dat de bemiddeling enkel kan worden bevolen op een moment vroeg genoeg in de procedure, enkel als de rechter van oordeel is dat een verzoening van de partijen kan worden overwogen in het licht van de elementen van het dossier en nadat de partijen zijn gehoord over de maatregel. De regering betoogt verder dat in verschillende landen al wordt afgeweken van het principe van de vrijwillige aard van de bemiddeling en dat ook het Hof van Justitie van de Europese Unie en het Europees Hof voor de Rechten van de Mens oordeelden dat een verplichte poging tot bemiddeling mogelijk is voor zover aan de partijen niet wordt belet hun recht op toegang tot de rechter uit te oefenen. ${ }^{30}$ 


\section{Het advies van de Hoge Raad voor Justitie}

11. Omdat het wetsontwerp mede betrekking had op de werking van de hoven en rechtbanken werd het advies ingewonnen van de Hoge Raad voor de Justitie (HRJ). ${ }^{31}$ De HRJ juichte toe dat het wetsontwerp, in de mate van het mogelijke, vormen van minnelijke geschillenoplossing wil aanmoedigen en bevorderen, maar had toch een reeks kritische bedenkingen. Het aan de HRJ voorgelegde wetsontwerp zou, als het wordt aangenomen, tot een 'paradigmaverschuiving' leiden. De minnelijke oplossing van geschillen zou de eerste en natuurlijke weg worden, en het beroep op rechters zou niet meer zijn dan een vangnet indien andere minnelijke oplossingstrajecten niet mogelijk blijken. Er zou in zekere mate een privatisering van justitie ontstaan. De toegang tot de rechtbank, en dus ook de juridische oplossing van geschillen tussen rechtzoekenden zouden symbolisch minder belangrijk worden. Hoewel onderhandelde oplossingen zeker voordelen bieden, blijft het noodzakelijk om de burger een daadwerkelijke toegang tot justitie te garanderen. Verder dient gewaakt te worden over de onpartijdigheid van de rechter die een geschil zou moeten beslechten wanneer de partijen er niet in geslaagd zijn om het minnelijk op te lossen. ${ }^{32}$ De HRJ was van mening dat het beter is dat een rechter een bemiddeling niet ambtshalve kan bevelen. De HRJ

'is van oordeel dat de rol van de rechter zich best beperkt tot het ervoor zorgen dat de partijen (en hun advocaten) (een betere) kennis hebben van het bemiddelingsproces en van de voor- en nadelen ervan. Op die manier kan een eventuele bemiddeling met volledige kennis van zaken plaatsvinden. De rol van de rechter is dan meer bescheiden, maar waarschijnlijk even effectief. ${ }^{33}$

Een dergelijk maatregel staat volgens de HRJ meer in verhouding tot de doelstellingen die het wetsontwerp nastreeft omdat ze het recht op een eerlijk proces en het beginsel van de vrijwilligheid van de bemiddeling niet beperkt. ${ }^{34}$ Het opleggen van bemiddeling kan leiden tot meer mislukkingen. De bevordering en de aanmoediging van de minnelijke schikking van geschillen kan ook via andere stimuleringsmaatregelen worden bereikt. ${ }^{35}$ Verder vond de HRJ het gevaarlijk dat de rechter de mogelijkheid zou krijgen om na te gaan of er reeds redelijke inspanningen werden geleverd om tot een minnelijke oplossing van geschillen te komen. Dit zou het recht op toegang tot de rechter beperken en de vertrouwelijkheid van de bemiddeling ondermijnen. Volgens de HRJ

'hoeft een burger niet uit te leggen waarom hij het legitiem acht om een minnelijke oplossing te weigeren en beroep te doen op de rechter. Vanuit juridisch en jurisdictioneel oogpunt, en vanuit het oogpunt van de algemene 
beginselen, moet het ontbreken van een overeenstemming immers de enige relevante factor blijven.' 36

Het zou de rechter toelaten de handelwijze te bestraffen van de persoon die in een gerechtelijke procedure de enige geloofwaardige of aanvaardbare manier ziet om het geschil tussen hem en een andere burger op te lossen. ${ }^{37}$ Wat de collaboratieve onderhandelingen betreft, was de HRJ van oordeel dat het feit dat de rechter zou kunnen bevelen om in een dergelijk proces te stappen, afbreuk zou doen aan het recht op toegang tot justitie. ${ }^{38}$ De partijen worden dan immers verplicht om een advocaat te nemen. ${ }^{39}$ Ten slotte vond de HRJ het paradoxaal dat een bemiddeling en een collaboratieve onderhandeling verplicht zouden kunnen worden opgelegd, maar een poging tot minnelijke schikking bij de rechter dan weer niet. De HRJ zag niet in hoe dit verschil in behandeling tussen de verschillende vormen van ADR zou kunnen worden gerechtvaardigd, zeker nu het ontwerp erop gericht was de verschillende vormen van minnelijke geschillenoplossing aan te moedigen. ${ }^{40}$

\section{De amendementen en de parlementaire bespreking}

12. Tijdens de commissiebespreking werden verschillende amendementen ingediend, zowel door leden van de meerderheid als van de oppositie. ${ }^{41}$ Zeer belangrijk was het uiteindelijk aangenomen amendement nr. 57 dat gericht was op een beperking van de mogelijkheden van de rechter om de partijen te verplichten tot een bemiddeling. Weliswaar wordt het principe bekrachtigd dat een rechter het beroep op bemiddeling kan opleggen, maar de rechter kan geen bemiddeling bevelen 'indien beide partijen daartegen gekant zijn'. Indien slechts één partij zich verzet tegen een bemiddeling kan zij dus nog steeds tot een verplichte bemiddelingspoging worden gedwongen. Een ander, niet aangenomen, amendement, nr. 91, strekte ertoe om de mogelijkheid tot het ambtshalve bevelen van een bemiddeling helemaal te schrappen, omdat een bemiddeling volstrekt vrijwillig is. Ten slotte kan de aandacht nog worden gevestigd op het niet aangenomen amendement nr. 78, dat erop gericht was de mogelijkheid tot een verplichte verwijzing naar de kamers voor minnelijke schikking in familiezaken af te schaffen, eveneens omdat dit vrijwillig zou moeten blijven.

39 Volgens het wetsontwerp ADR mogen enkel collaboratieve advocaten (die een speciale erkenning behoeven) collaboratieve onderhandelingen voeren.

40 Advies ADR, p. 7.

41 Amendementen bij het wetsontwerp houdende diverse bepalingen inzake burgerlijk recht en houdende wijziging van het Gerechtelijk Wetboek met het oog op de bevordering van alternatieve vormen van geschillenoplossing, Parl. St. Kamer 2017-18, nr. 54K2919/003; amendementen bij wetsontwerp houdende diverse bepalingen inzake burgerlijk recht en houdende wijziging van het Gerechtelijk Wetboek met het oog op de bevordering van alternatieve vormen van geschillenoplossing, Parl. St. Kamer 2017-18, nr. 54K2919/004. 
13. Uit het verslag van de commissiebesprekingen blijkt dat zowel parlementsleden van de meerderheid als van de oppositie ertegen gekant waren om aan de rechter de mogelijkheid te bieden de partijen te verplichten tot ADR. ${ }^{42}$ De argumenten die daarbij de revue passeerden waren in essentie de volgende:

- verplichte bemiddeling is in strijd met de per definitie vrijwillige aard van de bemiddeling;

- er kan van rechtsweigering gesproken worden en aan partijen wordt de toegang tot de rechter ontzegd;

- de termijnen worden nog langer als de bemiddeling geen akkoord oplevert;

- het is zeer de vraag of het opleggen van bemiddeling bijdraagt aan het welslagen van bemiddeling;

- de bemiddeling zal beter worden aanvaard en doeltreffender verlopen als ze vrijwillig plaatsvindt.

\section{De hoorzittingen}

14. Tijdens de bespreking in de commissie werden vertegenwoordigers gehoord van het Koninklijk Verbond van de Vrede- en Politierechters, de Hoge Raad voor Justitie, de Franstalige en Duitstalige balie, de orde van de Vlaamse balies, de federale bemiddelingscommissie, de Belgische Unie van Professionele Bemiddelaars, twee bemiddelaars en een familierechter. ${ }^{43}$ Het overgrote deel van hen stelde expliciet dat verplichte ADR op bevel van de rechter geen goede piste is. De argumenten die hier naarvoren kwamen, kunnen als volgt worden samengevat:

- verplichte ADR kan contraproductief zijn;

- de kosten van ADR komen bovenop die van een gerechtelijke procedure;

- voor ADR moet de keuze en het initiatief bij de partijen liggen;

- $\quad$ er kan een privatisering van justitie optreden;

- de toegang tot de rechtbank wordt symbolisch minder belangrijk;

- het is noodzakelijk de burger een daadwerkelijke toegang tot justitie te garanderen;

- bemiddeling is in beginsel vrijwillig;

- rechtsbedeling is een openbare dienst die geen subsidiair karakter mag krijgen, maar een volwaardig geschillenbeslechtingskanaal moet blijven;

- maatwerk moet mogelijk zijn, in die zin dat voor iedereen de meest geschikte oplossingswijze moet worden gevonden, ongeacht of dat via de gerechtelijke weg of ADR is;

- het sluiten van akkoorden mag niet tot een dogma worden verheven. Als een rechtzoekende zich wil onderwerpen aan het oordeel van een rechter moet dat kunnen;

- het verplichten van collaboratieve onderhandelingen doet afbreuk aan het beginsel dat men vrij zijn advocaat moet kunnen kiezen;

42 Verslag bij het wetsontwerp houdende diverse bepalingen inzake burgerlijk recht en houdende wijziging van het Gerechtelijk Wetboek met het oog op de bevordering van alternatieve vormen van geschillenoplossing, Parl. St. Kamer 2017-18, nr. 54K2919/006, p. 19-28 en 72-84.

43 Verslag bij het wetsontwerp houdende diverse bepalingen inzake burgerlijk recht en houdende wijziging van het Gerechtelijk Wetboek met het oog op de bevordering van alternatieve vormen van geschillenoplossing, Parl. St. Kamer 2017-18, nr. 54K2919/006, 92-166. 
- ADR kan rechtbanken niet vervangen;

- de ervaring leert dat gerechtelijke bemiddeling minder succesvol is dan een bemiddeling los van een gerechtelijke procedure;

- de partijen zullen slechts actief meewerken aan een bemiddeling als zij bereid zijn zelf hun conflict op te lossen. De wil om het conflict op te lossen moet aanwezig zijn;

- als partijen zelf kiezen voor een bemiddeling is dit effectiever;

- rechtzoekenden en advocaten verwachten in de eerste plaats dat de rechter een beslissing neemt. Bemiddeling beschouwen ze vaak als een rechtsweigering;

- als de partijen tot een bemiddeling worden verplicht bestaat het risico dat zij louter en alleen een attest zullen willen verkrijgen waaruit blijkt dat zij hebben deelgenomen aan de bemiddeling, maar er voor het overige snel zullen mee stoppen. Dit is contraproductief.

\section{Bijgestelde ambities}

15. De argumenten van de afdeling wetgeving van de Raad van State en van de Hoge Raad voor Justitie, de parlementsleden en de personen die tijdens de commissiezitting werden gehoord hebben ertoe geleid dat de oorspronkelijke tekst van het wetsontwerp werd bijgestuurd. De uiteindelijk goedgekeurde wet houdt op het vlak van het bevorderen of verplichten tot ADR door de rechter het volgende in.

- De rechter bevordert in elke stand van het geding een minnelijke oplossing van de geschillen. ${ }^{44}$ Deze bepaling strekt ertoe dat de rol van de rechter wordt verruimd: niet alleen beslecht hij juridische geschillen, hij speelt ook een rol in het oplossen van conflicten. Dit is iets wat in de realiteit al frequent gebeurde, zeker in familiezaken.

- Behoudens in kort geding kan de rechter, op de inleidingszitting of tijdens een zitting bepaald op een nabije datum, de partijen bevragen over de wijze waarop zij voorafgaand aan het geding gepoogd hebben het geschil minnelijk op te lossen en hen inlichten over de mogelijkheden om daar alsnog toe over te gaan. Daartoe kan de rechter de persoonlijke verschijning van de partijen bevelen. ${ }^{45}$ Hoewel de afdeling wetgeving van de Raad van State en de Hoge Raad voor Justitie zich erg kritisch opstelden ten aanzien van het bieden van de mogelijkheid aan de rechter om de partijen te ondervragen over hun inspanningen om tot minnelijke regelingen te komen, bleef deze regeling toch behouden. Rechtsleer, rechtspraak en de praktijk zullen in de toekomst moeten uitwijzen hoe rechters vorm geven aan deze mogelijkheid, hoe ver zij hierin willen gaan, of er sancties voortvloeien uit het nalaten van een (redelijke) poging tot minnelijke regeling, en of er sancties vastzitten aan de (onre- 
delijke) weigering om de rechter in te lichten over de ondernomen inspanningen om tot minnelijke oplossingen te komen.

- Op verzoek van een van de partijen of indien de rechter dit nuttig acht, kan hij, zo hij vaststelt dat verzoening mogelijk is, op diezelfde inleidingszitting of op een zitting bepaald op een nabije datum, de zaak verdagen naar een vaste datum die een maand niet mag overschrijden, behoudens akkoord van de partijen, teneinde hen in de gelegenheid te stellen om na te gaan of hun geschil geheel of deels op minnelijke wijze kan worden opgelost en om daarover alle nuttige inlichtingen in te winnen. Deze maatregel kan niet worden bevolen indien hij reeds werd bevolen in het kader van hetzelfde geschil. ${ }^{46}$ Met deze bepaling werd een evenwicht gezocht tussen enerzijds het bieden van een mogelijkheid om tot minnelijke regelingen te komen en anderzijds een voldoende snelle voortgang van de gerechtelijke procedure.

- Het behoort tot de opdracht van de rechter om de partijen te verzoenen. ${ }^{47}$ Reeds voor het invoeren van deze bepaling werd er van verschillende kanten op gewezen dat rechtsbedeling niet mag worden verengd tot rechtspraak en dat onder meer verzoening behoort tot de wezenlijke taak van de rechter. ${ }^{48}$ Zij behoort tot zijn natuurlijke bevoegdheden. ${ }^{49}$ De nieuwe wettelijke regeling bevestigt wat reeds vrij algemeen was aanvaard.

- Wanneer de rechter van mening is dat een verzoening tussen de partijen mogelijk is, kan hij, ambtshalve of op verzoek van een van de partijen, op de inleidingszitting, op een zitting waarop de zaak wordt verdaagd naar een nabije datum of op een zitting die ten laatste op de laatste dag van de maand die volgt op die van de neerlegging van de eerste conclusies van de verweerder, na de partijen gehoord te hebben, een bemiddeling bevelen. Dit geldt niet tijdens procedures voor het Hof van Cassatie en de arrondissementsrechtbank (deze trancheert enkel geschillen over de vraag welk rechtscollege bevoegd is). Indien alle partijen daartegen gekant zijn, kan de rechter geen bemiddeling bevelen. ${ }^{50}$ Deze bepaling opent de mogelijkheid voor de rechter om ambtshalve, dus zonder instemming van de partijen, een poging tot bemiddeling op te leggen, tenzij beide partijen zich daar uitdrukkelijk tegen zouden verzetten. Dit betekent dat één partij tegen haar wil tot een bemiddelingspoging kan worden gedwongen. Hoe ver de inspanningsverbintenis van de partijen reikt om deel te nemen aan een bemiddelingspoging zullen de praktijk en de rechtspraak gaandeweg moeten uitwijzen. Volstaat het om één keer 'aanwezig' te zijn of mag van de partijen worden verwacht dat zij hun best doen om tot een minnelijke regeling te komen? En hoe zal worden bewezen dat zij al of niet voldoende inspanningen leverden, gelet op de vertrouwe-

Art. 211 wet bevordering ADR.

Art. 212 wet bevordering ADR.

Zie bijv. K. Allegaert \& B. Luyten, De rechter-bemiddelaar naast de rechter-beoordelaar, Not. Fisc. M. 2004/8, p. 205; G. Rommel, De rechterlijke verzoening, jurisdisctionele aard en betekenis, TPR 1999, p. 7-50.

9 S. De Bauw \& B. Gayse, Bemiddeling en rechtspraak hand in hand. Wegwijs voor de rechter, Brugge: Die Keure 2009, p. 42.

Art. 225 wet bevordering ADR. 
lijkheid van de bemiddeling? Tegen het bevel van de rechter om een bemiddelingspoging te ondernemen staat geen rechtsmiddel - bijv. hoger beroep open. ${ }^{51}$

- In elke stand van het geding, alsook in kort geding, kan de rechter voor wie een zaak hangende is, op gezamenlijk verzoek van de partijen en na hen gehoord te hebben over de beoogde maatregel, zolang de zaak niet in beraad is genomen bevelen hun geschil door een collaboratieve onderhandeling trachten op te lossen. Dit geldt niet tijdens procedures voor het Hof van Cassatie en de arrondissementsrechtbank. ${ }^{52}$ Uit deze bepaling blijkt dat de rechter geen collaboratieve onderhandelingen kan opleggen tegen de wil van de partijen.

16. De verruimde opdrachten en taken van de rechter mogen niet los worden gezien van de verplichtingen die ook aan andere juridische professionals werden opgelegd, met name advocaten en gerechtsdeurwaarders. Zij zullen immers een cruciale rol spelen om er eventueel voor te zorgen dat een zaak nooit tot bij de rechter komt. Advocaten dienen de rechtzoekenden te informeren over de mogelijkheid tot bemiddeling, verzoening en elke andere vorm van minnelijke oplossing van geschillen. ${ }^{53}$ Indien advocaten van mening zijn dat een minnelijke oplossing van het geschil overwogen kan worden, dienen zij die in de mate van het mogelijke trachten te bevorderen. ${ }^{54}$ Ten slotte lijkt uit de wet voort te vloeien dat van advocaten mag worden verwacht dat zij pogingen ondernemen om een geschil minnelijk op te lossen vooraleer een geding wordt ingeleid. Dat staat niet met zoveel woorden in de wet, maar het nieuwe artikel 730/1, § 2 van het Gerechtelijk Wetboek ${ }^{55}$ bepaalt wel dat de rechter op de inleidingszitting of tijdens een zitting bepaald op een nabije datum de partijen kan bevragen over de wijze waarop zij voorafgaand aan het geding gepoogd hebben om het geschil minnelijk op te lossen. De wet schrijft niet voor dat de partijen verplicht zijn dergelijke pogingen te ondernemen, maar het vooruitzicht dat zij daarover door de rechter kunnen worden ondervraagd brengt wellicht mee dat zij zich toch enigszins onder druk gezet kunnen voelen om pogingen tot een minnelijke regeling te ondernemen of, als zij dat niet doen, daarvoor een goede uitleg voor te bereiden. De wet heeft het over 'de partijen', maar in de praktijk laten deze zich meestal bijstaan of vertegenwoordigen door een advocaat, zodat de vraag naar minnelijke oplossingspogingen (ook) aan de advocaat kan worden gesteld en er ook ten aanzien van hem een verwachting bestaat om de zaak eerst te proberen minnelijk te regelen. Het dient gezegd dat over de draagwijdte van de verplichtingen van de advocaat het laatste woord nog niet is gezegd. Het is absoluut onduidelijk hoe ver deze precies reiken. Nog veel onduidelijker is het hoe de nakoming ervan in de praktijk kan worden afgedwongen. Deze kwesties bieden op zich genoeg stof voor een afzonderlijk onderzoek, zodat er hier niet dieper op wordt ingegaan. Ook van gerechtsdeur-

51 Art. 226 wet bevordering ADR.

52 Art. 230 wet bevordering ADR.

53 Art. 205 wet bevordering ADR.

54 Art. 205 wet bevordering ADR.

55 Zoals ingevoegd door art. 211 wet bevordering ADR. 
waarders wordt verwacht dat zij de rechtzoekende in de mate van het mogelijke informeren over de mogelijkheid tot bemiddeling, verzoening en elke andere vorm van minnelijke oplossing van geschillen. Indien zij van mening zijn dat een minnelijke oplossing van het geschil kan worden overwogen, trachten zij die in de mate van het mogelijke te bevorderen. ${ }^{56}$

17. Hoewel het oorspronkelijk wetsontwerp werd afgezwakt, mag men toch concluderen dat de nieuwe wetgeving nog steeds ambitieus is op het vlak van het bevorderen van of zelfs verplichten tot ADR. Zij biedt de rechter heel wat gereedschappen om partijen richting ADR te leiden.

\section{Conclusies}

18. De Europese bemiddelingsrichtlijn heeft als doel de toegang tot de alternatieve geschillenbeslechting te vergemakkelijken en de minnelijke schikking van geschillen te bevorderen door het gebruik van bemiddeling (mediation) aan te moedigen en te zorgen voor een evenwichtige samenhang tussen bemiddeling en behandeling in rechte. ${ }^{57}$ Bij uitbreiding kan men stellen dat de uitdaging erin ligt om bij het oplossen van geschillen tot een goed evenwicht te komen tussen rechtspraak en ADR. Dat is niet evident. Uit de zogenoemde 'bemiddelingsparadox' blijkt dat, hoewel bemiddeling op een hoge succes- en tevredenheidsratio kan bogen, er zelden gebruik van wordt gemaakt. ${ }^{58}$ Dat is ook het geval voor andere vormen van $A D R$. Tal van ideeën om $A D R$ te stimuleren of zelfs te verplichten zagen het daglicht, maar telkens opnieuw stuitten zij op tal van bewaren. Het gaat daarbij om principiële bezwaren (ADR moet vrijwillig zijn), juridische bezwaren (het recht op toegang tot de rechter mag niet worden aangetast) en praktische bezwaren (gedwongen ADR werkt toch niet, dit zal snel ontaarden in een hol formalisme). De Belgische regering werkte een ambitieus voorontwerp van wet uit dat ADR de wind in de zeilen moest geven. Tijdens de bespreking moesten die ambities worden bijgesteld omdat er van diverse zijden bezwaren werden geuit. Gezaghebbende instanties zoals de afdeling wetgeving van de Raad van State en de Hoge Raad voor Justitie, parlementsleden van meerderheid en oppositie, vertegenwoordigers van beroepsorganisaties en instellingen bleken over het algemeen sceptisch te staan tegen een verplichte ADR-poging. De parlementaire bespreking van de nieuwe wet bevordering ADR illustreert dit treffend. De afde-

56 Art. 206 wet bevordering ADR.

57 Art. 1 lid 1 Richtlijn 2008/52/EG van het Europees Parlement en de Raad van 21 mei 2008 betreffende bepaalde aspecten van bemiddeling/mediation in burgerlijke en handelszaken, $\mathrm{PbEU}$ 2008, L 136. Deze richtlijn is enkel toepasselijk op grensoverschrijdende geschillen, maar blijkens de preambule ervan belet niets de lidstaten de bepalingen van de richtlijn ook op hun interne bemiddelings-/mediationprocedures toe te passen (overweging 8).

58 G. De Palo, L. D’Urso, M. Trevor, B. Branon, R. Canessa, B. Cawyer \& L.R. Florence, Rebooting the mediation directive: assessing the limited impact of its implementation and proposing measures to increase the number of mediations in the EU, Brussel, Europese Unie, Directorate-general for internal policies - Policy department C., 2014, www.europarl.europa.eu/RegData/etudes/ etudes/join/2014/493042/IPOL-JURI_ET(2014)493042_EN.pdf, p. 118-119. 
ling wetgeving van de Raad van State en de hoge Raad voor Justitie hadden ook moeite met het feit dat ADR de eerste weg zou moeten worden, waardoor rechtspraak als een soort vangnet, als laatste optie zou moeten fungeren. Een dergelijke 'paradigmawissel' op het vlak van conflictoplossing werd niet acceptabel geacht. Het resultaat van dat alles was een compromis dat toch nog altijd een serieuze boost kan geven aan ADR. Bemiddeling wordt tot op zekere hoogte verplicht, in die zin dat een bemiddelingspoging nog steeds kan worden bevolen indien niet alle partijen zich daartegen verzetten. Eén partij zal dus tegen haar wil tot een bemiddeling kunnen worden gedwongen.

19. De praktijk zal moeten uitwijzen wat de impact is van de wet bevordering ADR. Veel zal afhangen van de advocatuur, die ingevolge de nieuwe wet verplicht wordt de rechtzoekende te informeren over de mogelijkheden tot ADR en, indien zij van mening is dat een minnelijke oplossing van het geschil kan worden overwogen, moet trachten die in de mate van het mogelijke te bevorderen. Maar minstens even veel zal afhangen van de bereidheid van de partijen om een ADR-traject te beproeven en inspanningen te leveren om tot een resultaat te bekomen. De wetgever mag dan wel de partijen een duwtje in de rug geven, tegelijkertijd dient men te beseffen dat wat men kan bereiken met rechtsregels ook zijn grenzen heeft. Of het wat wordt met ADR hangt in de eerste plaats af van een cultuur- en mentaliteitsomslag, wat niet wegneemt dat de wetgever kan bijdragen tot die omslag. 